\title{
Interaction between substance P and TRH in the control of prolactin release
}

\author{
B H Duvilanski, D Pisera, A Seilicovich, M del Carmen Díaz, \\ M Lasaga, E Isovich and M O Velardez
}

Centro de Investigaciones en Reproducción, Facultad de Medicina, Universidad de Buenos Aires, Argentina

(Requests for offprints should be addressed to B H Duvilanski, Centro de Investigaciones en Reproducción, Facultad de Medicina, Piso 10, Universidad de Buenos Aires, Paraguay 2155 (1121) Buenos Aires, Argentina; Email: duvilan@mail.retina.ar)

\begin{abstract}
Substance P (SP) may participate as a paracrine and/or autocrine factor in the regulation of anterior pituitary function. This project studied the effect of TRH on SP content and release from anterior pituitary and the role of $\mathrm{SP}$ in TRH-induced prolactin release. TRH $\left(10^{-7} \mathrm{M}\right)$, but not vasoactive intestinal polypeptide (VIP), increased immunoreactive-SP (ir-SP) content and release from male rat anterior pituitary in vitro. An anti-prolactin serum also increased ir-SP release and content. In order to determine whether intrapituitary SP participates in TRH-induced prolactin release, anterior pituitaries were incubated with TRH $\left(10^{-7} \mathrm{M}\right)$ and either WIN 62,577, a specific antagonist of the NK1 receptor, or a specific anti-SP serum. Both WIN 62,577 $\left(10^{-8}\right.$ and $\left.10^{-7} \mathrm{M}\right)$ and the anti-SP serum (1:250) blocked TRH-induced prolactin
\end{abstract}

release. In order to study the interaction between TRH and SP on prolactin release, anterior pituitaries were incubated with either TRH $\left(10^{-7} \mathrm{M}\right)$ or SP, or with both peptides. SP $\left(10^{-7}\right.$ and $\left.10^{-6} \mathrm{M}\right)$ by itself stimulated prolactin release. While $10^{-7} \mathrm{M}$ SP did not modify the TRH effect, $10^{-6} \mathrm{M}$ SP reduced TRH-stimulated prolactin release. SP $\left(10^{-5} \mathrm{M}\right)$ alone failed to stimulate prolactin release and markedly decreased TRH-induced prolactin release. The present study shows that TRH stimulates ir-SP release and increases ir-SP content in the anterior pituitary. Our data also suggest that SP may act as a modulator of TRH effect on prolactin secretion by a paracrine mechanism.

Journal of Endocrinology (2000) 166, 373-380

\section{Introduction}

Substance P (SP), a neuropeptide belonging to the tachykinin family, is found in most tissues, and produces a broad range of cellular responses. SP exerts its effects through a specific receptor in a $G$ protein-linked family of receptors. It enhances polyphosphoinositide breakdown and increases intracellular free calcium levels (Mau et al. 1990, Mau \& Saermark 1991). In the anterior pituitary, the preferred SP receptor, a neurokinin-1 (NK1) subtype of the tachykinin receptor family, is found exclusively in lactotrophs and gonadotrophs (Larsen et al. 1992).

SP is synthesized (Jessop et al. 1992) and released (Seilicovich et al. 1990, Arita et al. 1993) by the anterior pituitary. SP was found to be localized only in somatotrophs and thyrotrophs of male rats (Brown et al. 1991, Arita et al. 1994). Also SP-like immunoreactive innervation is present in the anterior pituitary, distributed around secretory cells such as lactotrophs (Liu et al. 1996) and corticotrophs (Ju et al. 1991) and around blood vessels (Mikkelsen et al. 1989).

SP content and preprotachykinin mRNA vary with age and sex of the animals; it is higher in male than in female rats (Yoshikawa \& Hong 1983, Jessop et al. 1992). SP content in the anterior pituitary is regulated by several circulating hormones (De Palatis et al. 1985, Jonnassen et al. 1987, Aronin et al. 1988, O'Halloran et al. 1990, Jones et al. 1994).

SP modulates several anterior pituitary hormones (Jessop et al. 1992). SP stimulates in vitro prolactin release from the anterior pituitary (Vijayan \& McCann 1979, Seilicovich et al. 1993), while the blockade of intrapituitary SP with specific SP antibodies decreases basal prolactin release (Afione et al. 1990a).

Thyrotropin-releasing hormone (TRH) is a hypophysiotropic neuropeptide that increases thyrotropin (TSH) and prolactin secretion. TRH is synthesized not only in the hypothalamus but also in a subpopulation of somatotrophs in the anterior pituitary (Bruhn et al. 1994).

Several studies have demonstrated the modulatory role of some pituitary peptides on hypothalamic neurotransmitters and neuropeptides that regulate anterior pituitary hormone secretion (Peillon et al. 1997). Interactions between neurotransmitters and SP or vasoactive intestinal polypeptide (VIP) at pituitary level (Afione et al. 1990a,b, Duvilanski et al. 1990, Apfelbaum 1998), and also 
between VIP and TRH (Balsa et al. 1996) have been described.

Since SP has a paracrine effect on prolactin secretion, the aim of this study was to ascertain whether anterior pituitary SP is involved in the effect of TRH on prolactin release. Therefore, we designed our experiments in order to study: (1) the influence of SP blockade on the effect of $\mathrm{TRH}$ on prolactin release; (2) the effect of TRH on anterior pituitary SP release and content; and (3) the interaction between TRH and SP in the control of prolactin release.

\section{Materials and Methods}

Male Wistar rats (200-250 g) were kept in controlled conditions of light (12 h light : $12 \mathrm{~h}$ darkness) and temperature $\left(21-24^{\circ} \mathrm{C}\right)$. Lab chow and water were supplied and animals were allowed to feed ad libitum. The rats were kept according to the NIH Guide for the Care and Use of Laboratory Animals. Rats were killed by decapitation and the anterior pituitary lobes removed, then placed in Krebs-Ringer bicarbonate buffer, $\mathrm{pH} 7 \cdot 4$, containing $10 \mathrm{mM}$ glucose, $25 \mathrm{mM}$ Hepes, $0 \cdot 1 \mathrm{mM}$ bacitracin, $0 \cdot 1 \%$ ascorbic acid and $0 \cdot 1 \%$ bovine serum albumin (KRB buffer).

All drugs were purchased from Sigma (St Louis, MO, USA), except TRH, SP and VIP (Peninsula Lab. Inc., Belmont, CA, USA), and WIN 62,577 (Research Biochemical Int., Natick, MA, USA). Rat prolactin and NIDDK anti-prolactin serum (S-9) were kindly supplied by the National Hormone and Pituitary Program (Torrance, CA, USA).

Rabbit anti-SP serum was prepared, characterized and tested as previously reported (Debeljuk et al. 1988). This anti-serum showed no cross-reactivity with other mammalian neuropeptides such as neurokinin A, neurokinin B, VIP, neuromedin B and neurotensin when these peptides were tested at doses 5000-10 000-fold higher than those of SP.

\section{Dynamic incubation of anterior pituitary glands. Pulse-chase experiments}

Five pituitaries were placed into a small perforated basket and immersed in a tube containing $1 \mathrm{ml}$ of $\mathrm{KRB}$ buffer and pre-incubated for $30 \mathrm{~min}$ at $37^{\circ} \mathrm{C}$, in an atmosphere of $95 \% \mathrm{O}_{2}-5 \% \mathrm{CO}_{2}$, with constant shaking of 60 cycles per min. Basal release was then determined by incubating the baskets for two periods of $15 \mathrm{~min}$ in fresh KRB buffer. Afterwards, the baskets were transferred to a tube containing TRH $\left(10^{-7} \mathrm{M}\right.$ ) and incubated for $5 \mathrm{~min}$ (TRH pulse). Finally, post-stimulus release was assessed by incubating the baskets for two periods of $15 \mathrm{~min}$ in KRB buffer. Controls were run in parallel with KRB buffer only. The media were immediately acidified, frozen on dry ice and processed for SP determination. An aliquot of each medium was separated before acidification and stored at $-20{ }^{\circ} \mathrm{C}$ until prolactin determination.

\section{Static incubation of anterior pituitary glands}

Three pituitaries per tube were used to assay SP and prolactin release in each incubation, and only one when prolactin release alone was studied. The pituitaries were pre-incubated for $60 \mathrm{~min}$ in $1 \mathrm{ml} \mathrm{KRB}$ buffer. Afterwards, the tissue was incubated for another $60 \mathrm{~min}$, unless otherwise indicated, in $1 \mathrm{ml}$ of fresh KRB buffer containing the different drugs studied. Controls were incubated with medium alone or vehicle or normal rabbit serum (NRS). At the end of the incubation period, media were aspirated. Media and tissues were immediately acidified, frozen on dry ice and processed for SP determination. An aliquot of medium was separated before acidification, and stored at $-20{ }^{\circ} \mathrm{C}$ until prolactin determination. WIN 62,577 is a non-peptide NK1 receptor antagonist that binds to rat brain homogenates with $K_{\mathrm{i}}$ values of $21 \mathrm{nM}$ (Appel et al. 1991). WIN 62,577 was dissolved in DMSO and diluted in KRB buffer. A final concentration of $0.02 \%$ DMSO had no effect on basal prolactin release.

\section{SP determination}

Media and tissues were heated at $100{ }^{\circ} \mathrm{C}$ for $5 \mathrm{~min}$ in $1 \mathrm{M}$ acetic acid. The tissues were then homogenized and both media and tissues centrifuged at 14500 r.p.m. for $20 \mathrm{~min}$. The supernatants were lyophilized and stored at $-70{ }^{\circ} \mathrm{C}$ until SP determination. SP was measured by double antibody radioimmunoassay with ${ }^{125} \mathrm{I}$-SP as tracer, as previously described (Seilicovich et al. 1990). The intraand interassay coefficients of variation were under $10 \%$. Immunoreactive SP (ir-SP) was expressed as ng/mg protein. Protein concentration of tissue pellets was determined by Lowry's method.

\section{Prolactin determination}

Prolactin was measured in the incubation medium by a double antibody radioimmunoassay, with kits provided by the National Hormone and Pituitary Program. Results were expressed in terms of rat prolactin RP-3 standard. The intra- and interassay coefficients of variation were less than $9 \%$.

\section{Statistical analysis}

Results were expressed as means \pm s.E.M.s and evaluated by the Student $t$-test or by one- or two-way analysis of variance (ANOVA) followed by Student-Newman-Keuls multiple comparison test for unequal replicates or 
Table 1 Effect of WIN 62,577 on basal and SP-induced prolactin release. Anterior pituitaries were incubated for $60 \mathrm{~min}$ in the presence of increasing concentrations of WIN 62,577 (WIN), a specific SP receptor antagonist, with or without SP. Data are means \pm S.E.M. $(n=6)$

\begin{tabular}{|c|c|c|}
\hline & \multicolumn{2}{|c|}{ Prolactin ( $\mu \mathrm{g} / \mathrm{mg}$ protein) } \\
\hline & No SP added & $\mathrm{SP}\left(10^{-6} \mathrm{M}\right)$ \\
\hline Control & $1 \cdot 35 \pm 0 \cdot 10$ & $1 \cdot 71 \pm 0.09 *$ \\
\hline WIN $\left(10^{-8} \mathrm{M}\right)$ & $1 \cdot 47 \pm 0 \cdot 11$ & $1 \cdot 47 \pm 0 \cdot 08$ \\
\hline WIN $\left(10^{-7} \mathrm{M}\right)$ & $1 \cdot 27 \pm 0 \cdot 05$ & $1 \cdot 32 \pm 0 \cdot 08 \dagger$ \\
\hline WIN $\left(10^{-6} \mathrm{M}\right)$ & $0.82 \pm 0.08 \dagger$ & - \\
\hline
\end{tabular}

${ }^{*} P<0.01$ vs respective control without $S P,+P<0.01$ vs respective control without WIN. Statistical significance was determined by two-way ANOVA followed by Student-Newman-Keuls post hoc test.

Dunnett's test. The differences between groups were considered significant if $P<0 \cdot 05$. Results were confirmed by at least three independent experiments.

\section{Results}

Effect of the blockade of intrapituitary SP on TRH-induced prolactin release

WIN 62,577 $\left(10^{-6} \mathrm{M}\right)$, a specific antagonist of the NK1 receptor, inhibited basal prolactin release. Lower concentrations of the receptor antagonist $\left(10^{-8}-10^{-7} \mathrm{M}\right)$ had no effect on prolactin release but significantly reduced SPinduced prolactin release (Table 1) and also blocked the stimulatory effect of TRH (Fig. 1). A specific anti-SP serum (1:250) did not modify basal prolactin release from anterior pituitaries incubated for $20 \mathrm{~min}$ but significantly decreased basal prolactin release after 60 min (Fig. 2A, B)

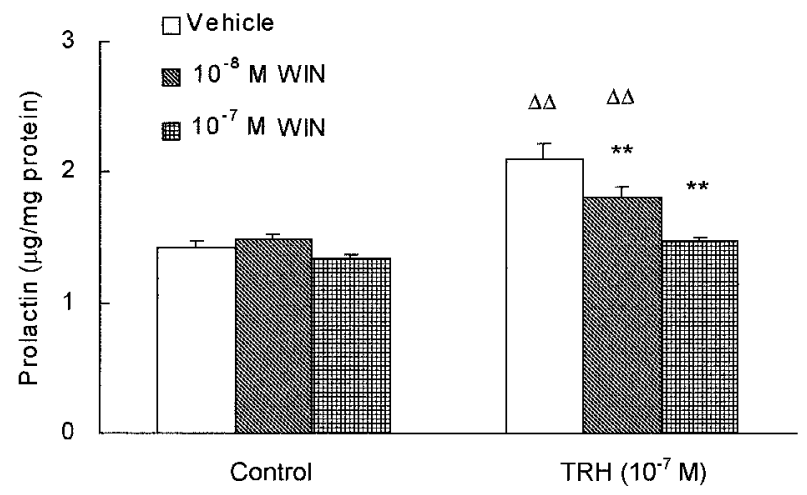

Figure $1 \mathrm{SP}$ receptor antagonist blocks TRH-induced prolactin release. Anterior pituitaries were incubated for $60 \mathrm{~min}$ with $10^{-7} \mathrm{M}$ TRH and/or WIN 62,577 (WIN). Bars represent means \pm S.E.M.S $(n=6)$. Statistical significance was determined by two-way ANOVA followed by Student-Newman-Keuls post hoc test. ${ }^{*} P<0 \cdot 01$ vs respective control without WIN. $\Delta \Delta P<0 \cdot 01$ vs respective control without TRH.
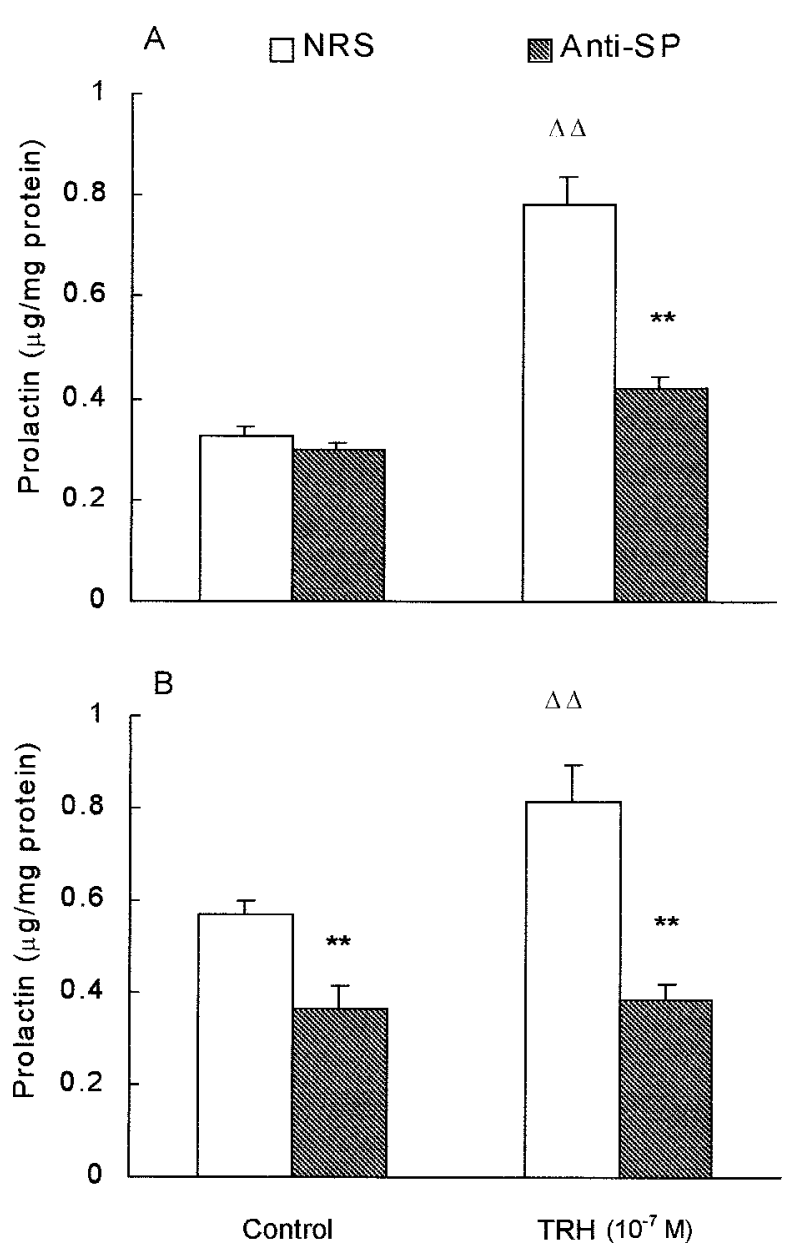

Figure 2 Anti-SP serum blocks TRH-induced prolactin release. Anterior pituitaries were incubated for 20 (A) and 60 (B) min with $10^{-7} \mathrm{M}$ TRH and anti-SP serum (Anti-SP, final dilution 1:250). Controls were incubated with normal rabbit serum (NRS, final dilution 1:250). Bars represent means \pm S.E.M.S $(n=5)$. Statistical significance was evaluated by two-way ANOVA followed by Student-Newman-Keuls post hoc test. ${ }^{* *} P<0.01$ vs respective control without Anti-SP. $\Delta \Delta P<0 \cdot 01$ vs respective control without TRH.

and inhibited TRH-induced prolactin release in both incubation periods (Fig. 2A, B).

\section{Effect of TRH on ir-SP release}

Since intrapituitary SP seems to be involved in the stimulatory effect of TRH on prolactin release, we examined whether TRH affects SP release. TRH $\left(10^{-7} \mathrm{M}\right)$ stimulated ir-SP release and increased tissue content of ir-SP in anterior pituitary incubated in static conditions (Fig. 3). TRH also stimulated prolactin release (control: $0.823 \pm 0.053 \mu \mathrm{g} / \mathrm{mg}$ protein; $10^{-7} \mathrm{M} \mathrm{TRH}$ : $1 \cdot 817 \pm 0 \cdot 111, n=7, P<0 \cdot 01)$. In dynamic incubation of anterior pituitary, a 5 -min pulse-chase with $10^{-7} \mathrm{M}$ 


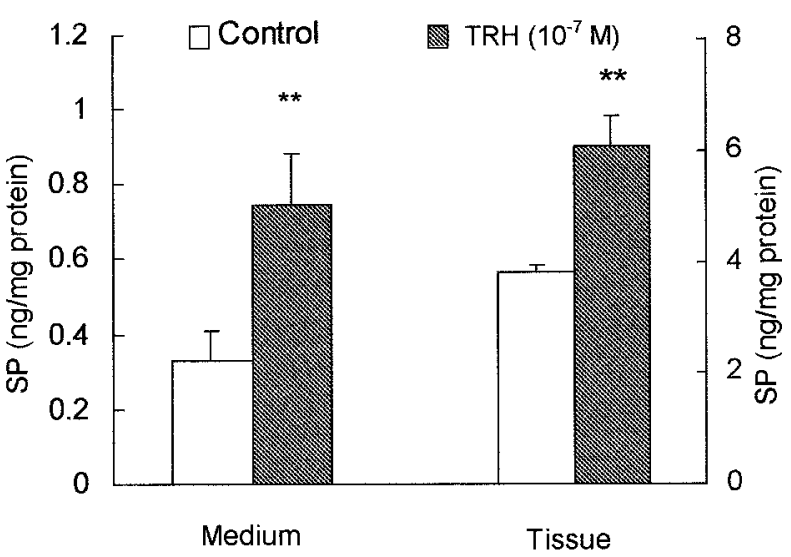

Figure 3 TRH stimulates ir-SP release and ir-SP content in anterior pituitary. Anterior pituitaries were incubated for $60 \mathrm{~min}$ in the presence of TRH or KRB (control). Bars represent means \pm S.E.M.S $(n=6)$. Basal release of ir-SP was $0.200 \pm 0.013 \mathrm{fmol} / \mathrm{ml}$ per anterior pituitary. Statistical differences between TRH and control were determined by Student's $t$-test. ${ }^{*} P<0 \cdot 01$.

TRH significantly increased ir-SP release vs control values. This increase persisted throughout the incubation period (Fig. 4). The concentration of ir-SP released in the last fraction was $28 \cdot 50 \pm 0 \cdot 11 \mathrm{fmol} / \mathrm{ml}$ per anterior pituitary. SP released after TRH pulse-chase stimulus was approximately fourfold higher than that found in the 60-min period of uninterrupted static incubation with TRH. Prolactin release increased 15 min after the TRH pulse $(1.623 \pm 0.08 \mu \mathrm{g} / \mathrm{ml}$ per anterior pituitary), then lowered to basal values (Fig. 4).

\section{Effect of prolactin on ir-SP release}

In order to evaluate the influence of prolactin on the effect of TRH on SP release, anterior pituitaries were incubated with VIP, another prolactin-releasing factor. VIP increased prolactin release (control: 0.941 $\pm 0.028 \mu \mathrm{g} / \mathrm{mg}$ protein; $10^{-7} \mathrm{M}$ VIP: $\left.1.539 \pm 0 \cdot 121, P<0 \cdot 01\right)$, but did not affect ir-SP release (control: $0.776 \pm 0.031 \mathrm{ng} / \mathrm{mg}$ protein; $10^{-7} \mathrm{M}$ VIP: $\left.0 \cdot 718 \pm 0 \cdot 034 ; n=5\right)$. On the other hand, anti-prolactin serum increased ir-SP release and content. TRH and the anti-prolactin serum together had no additive effect on ir-SP release (Fig. 5).

\section{Effect of simultaneous presence of TRH and SP on prolactin release}

In order to study the interaction between TRH and SP in prolactin release, anterior pituitaries were incubated with either TRH or SP alone or both peptides together. Prolactin release was stimulated by increasing TRH concentrations (control: $1.022 \pm 0.040 \mu \mathrm{g} / \mathrm{mg}$ protein; $10^{-9}$ M TRH: $1 \cdot 209 \pm 0 \cdot 042 ; 10^{-8}$ M TRH: $1 \cdot 352 \pm$ $0 \cdot 037 \star ; 10^{-7}$ M TRH: $1 \cdot 489 \pm 0 \cdot 100 \star \star ; 10^{-6}$ M TRH:

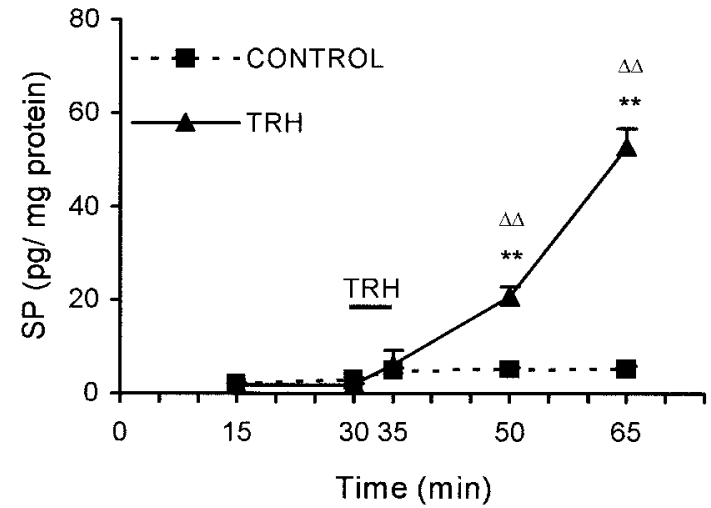

A

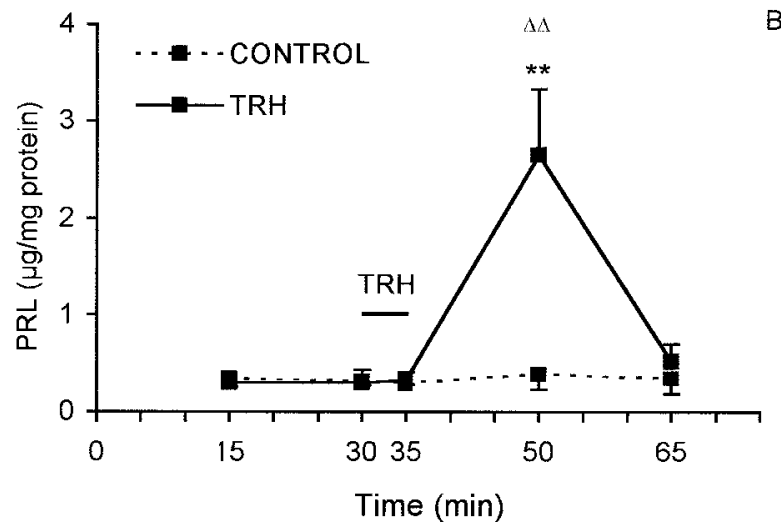

Figure 4 TRH stimulates ir-SP release and prolactin from anterior pituitary. Release of SP from anterior pituitary was evaluated by dynamic incubations as described in Materials and Methods. After $30 \mathrm{~min}$ of incubation (basal release), $10^{-7} \mathrm{M}$ TRH was added for 5 min. Controls were run in parallel with KRB only. Values represent means \pm S.E.M.S of ir-SP (A) and prolactin (B) released in each fraction of the incubation period indicated $(n=6)$. Basal release of ir-SP was $1.75 \pm 0.06 \mathrm{fmol} / \mathrm{ml}$ per anterior pituitary. Statistical differences between basal and post-pulse release $\left({ }^{*} P<0 \cdot 01\right)$ were determined by Dunnett's test. Statistical differences between the TRH and control groups for each time period $(\Delta \Delta P<0 \cdot 01)$ were determined by Student's $t$-test.

$1 \cdot 642 \pm 0 \cdot 069 \star \star, n=7, \star P<0 \cdot 05, \star \star x<0 \cdot 01$ vs control, Dunnett's test). When anterior pituitaries were incubated simultaneously with $10^{-7} \mathrm{M}$ TRH and $10^{-7} \mathrm{M}$ SP, the stimulatory effect of the two peptides together on prolactin release was similar to that observed for each alone (Fig. 6). SP at a concentration of $10^{-6} \mathrm{M}$ also stimulated prolactin release but significantly reduced TRH-induced prolactin release, while $10^{-5} \mathrm{M}$ SP, which failed to affect prolactin release, markedly decreased TRH stimulus.

\section{Discussion}

This study shows that TRH enhances ir-SP release from the anterior pituitary and that intrapituitary SP participates 

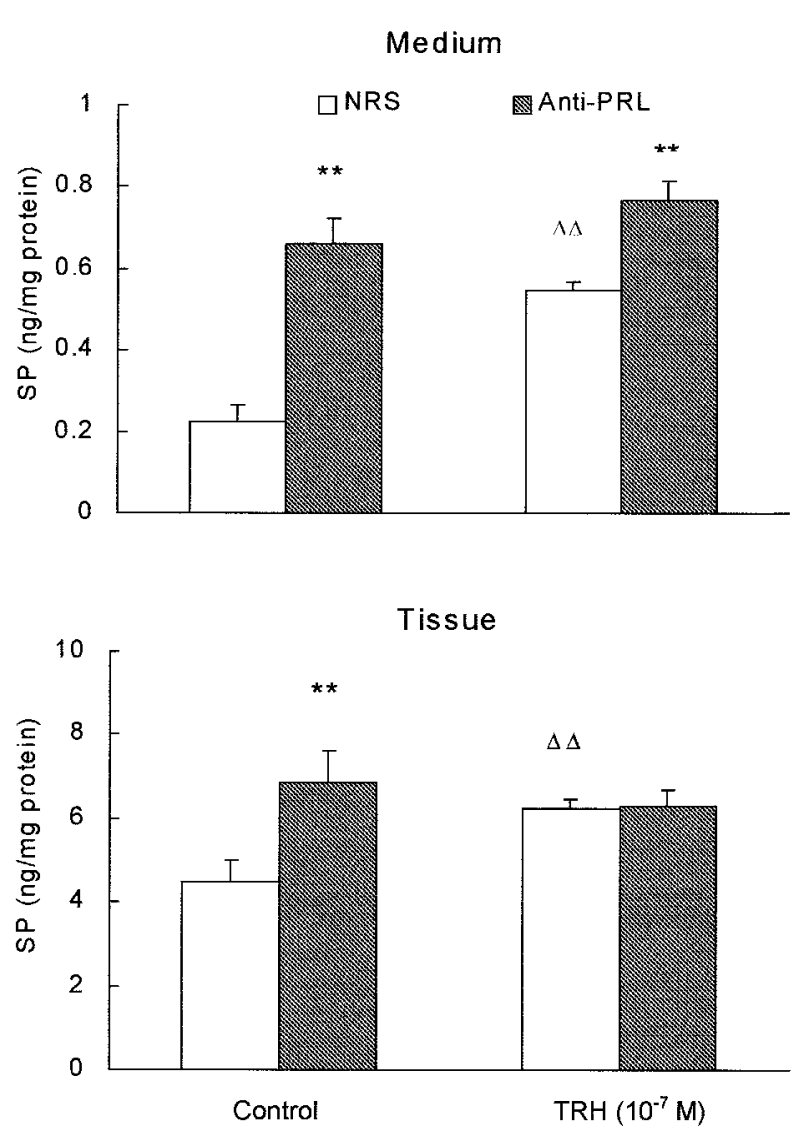

Figure 5 Effect of anti-prolactin serum on TRH-stimulated ir-SP release and content. Anterior pituitaries were incubated for $60 \mathrm{~min}$ with $10^{-7} \mathrm{M} \mathrm{TRH}$ and anti-prolactin serum (Anti-PRL, final dilution 1:200). Controls were incubated with normal rabbit serum (NRS, final dilution 1:200). Bars represent means \pm S.E.M.s $(n=5)$. Basal release of ir-SP was $0.183 \pm 0.033 \mathrm{fmol} / \mathrm{ml}$ per anterior pituitary. Statistical significance was determined by two-way ANOVA followed by Student-Newman-Keuls post hoc test. ${ }^{*} P<0.01$ vs respective control without Anti-PRL. $\Delta \Delta P<0 \cdot 01$ vs respective control without TRH.

in TRH-induced prolactin release. TRH increased both prolactin and SP release. Said increases induced by TRH were higher when TRH was tested as a pulse (for $5 \mathrm{~min}$ ) than when it was present for $60 \mathrm{~min}$ (static incubation). Rapid desensitization is characteristic of most native $\mathrm{Gq} / 11$-coupled receptors, like those for TRH or SP, in the permanent presence of an agonist (Sanders \& LeVine 1996, Bhom et al. 1997, Yu \& Hinkle 1998). Therefore, it is possible that continuous stimulation with TRH may desensitize the receptor. The effect of TRH on ir-SP does not seem to be a consequence of increased prolactin concentration since an increase of prolactin release induced by VIP did not affect ir-SP release. Also, an anti-prolactin serum increased basal ir-SP release, suggesting that the reduction of extracellular prolactin may increase ir-SP release. Similarly, others reported that chronic treatment with a dopamine agonist, which decreases prolactin release, increases SP mRNA but does not modify ir-SP content in the rat anterior pituitary, suggesting that prolactin may decrease the synthesis and release of SP (O'Halloran et al. 1991). Ovariectomy, which also decreases prolactin release, raises SP content (De Palatis et al. 1985), whereas oestrogen administration increases prolactin release and decreases anterior pituitary SP (O'Halloran et al. 1990). Therefore, our results suggest that TRH-induced SP release would not be mediated by prolactin.

Besides, both TRH and anti-prolactin serum increased ir-SP content in the anterior pituitary. This enhancement of SP content could result from processing of the preprotachykinin protein and/or translation of the stored preprotachykinin mRNA, which encodes for SP and NKA (Farrow 1993, Weintraub 1995).

We previously observed that a specific anti-SP serum reduces in vitro basal prolactin release (Afione et al. 1990a) and markedly decreases hyperprolactinemia induced by anterior pituitary grafting under the kidney capsule (Debeljuk et al. 1988). In the present study, the anti-SP serum blocked TRH-induced prolactin release. The specific NK1 receptor antagonist, WIN 62,577, also inhibited TRH-induced prolactin release, supporting our results for the anti-serum. The present results confirm previous reports suggesting that intrapituitary SP participates in the regulation of basal prolactin release and show that SP is involved in the effect of TRH on prolactin release from anterior pituitary of normal male rats. Reports by Balsa et al. (1996) demonstrated that intrapituitary VIP mediates TRH-induced prolactin release from anterior pituitary cells, this effect being partial and dependent on thyroid hormones.

The present study also found interaction between TRH and SP that affected prolactin release. Both peptides together in equimolar concentration increased prolactin release, although no additive effect was observed, thus supporting other reports indicating that $\mathrm{TRH}$ and SP could share an effector mechanism (Mau et al. 1990). However, when the concentration of SP was higher than that of TRH in the incubation medium, a decrease in the stimulatory effect of TRH on prolactin release was observed. SP was reported to interact not only with its own specific receptor, but also with others, including some outside its own receptor family (Simasko et al. 1987, Shamgochian \& Leeman 1992, Goettl \& Larson 1994, Maggi 1995). Sharif (1990) demonstrated that SP specifically reduced, in a concentration-dependent manner, $\mathrm{TRH}$ receptor binding in different areas of the central nervous system and in the pituitary gland. Although SP seems to compete with the TRH receptor, TRH does not compete with SP binding (Wormald et al. 1989). These facts and our results lead us to speculate that SP could interfere with TRH binding. Alternatively, it has been suggested that SP could affect post-receptor events, such 


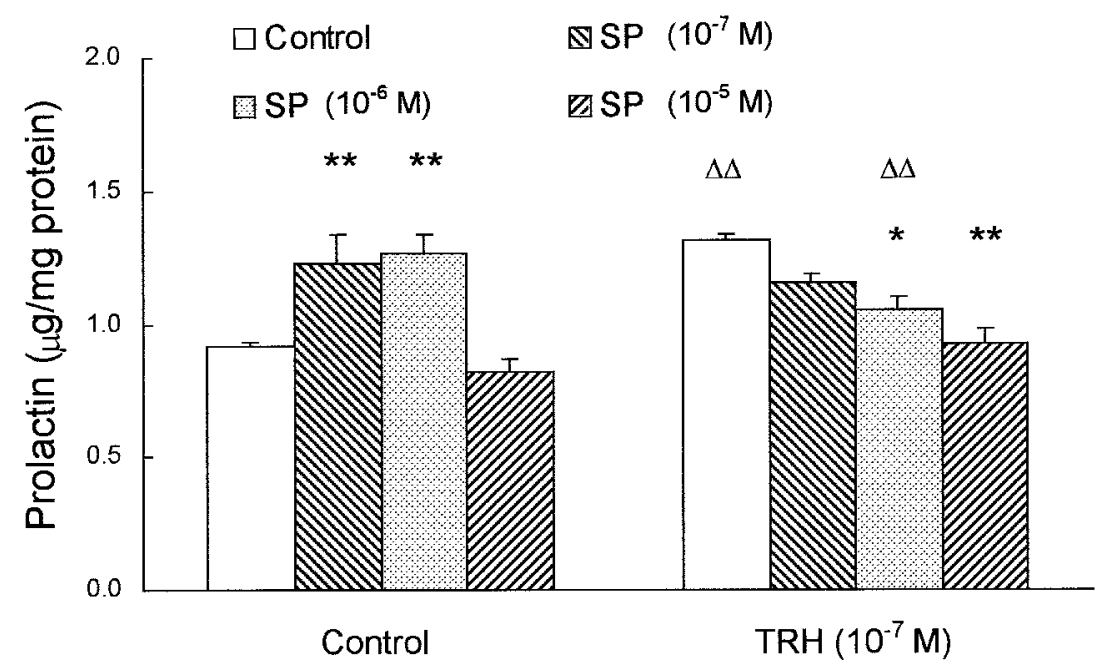

Figure 6 Effect of SP on TRH-induced prolactin release. Anterior pituitaries were incubated for 60 min with $10^{-7} \mathrm{M}$ TRH and increasing concentrations of SP. Bars represent means \pm S.E.M.S $(n=6-7)$. Statistical significance was evaluated by two-way ANOVA followed by Student-Newman-Keuls post hoc test. ${ }^{*} P<0 \cdot 05$; ${ }^{* *} P<0.01$ vs respective control without TRH. $\Delta \Delta P<0 \cdot 01$ vs respective control without SP.

as down-regulation of protein kinase $\mathrm{C}$ by high $\mathrm{SP}$ concentration (Ozawa et al. 1993).

Whatever the mechanism by which intrapituitary SP interacts with TRH in the control of prolactin release, SP may be relevant to the modulation of TRH action on lactotroph activity without modifying its effect on thyrotroph function (Arisawa et al. 1989). SP at low concentrations, such as those found in the environment of the target cell, may mediate TRH effect on prolactin release, while higher concentrations of SP may interfere with TRH effect on lactotrophs. Similarly, Shamgochian \& Leeman (1992) reported that the same concentration of SP that stimulates $\mathrm{LH}$ release $\left(10^{-6} \mathrm{M}\right)$ also displaces gonadotropin-releasing hormone $(\mathrm{GnRH})$ from anterior pituitary membranes. Also, SP inhibits GnRH-stimulated LH secretion from cultured pituitary cells (Wormald et al. 1989), suggesting that SP may act by preventing total exhaustion of the response capabilities of anterior pituitary cells.

Primary hypothyroidism shows sex-dependent changes in serum prolactin levels. Although hyperprolactinemia has been observed in female hypothyroid rats (Tohei et al. 1988), hypoprolactinemia is more frequent in both female and male hypothyroid rats (Sowers \& Sollars 1980, Lloyd et al. 1990, Mizukami et al. 1993, Kimura \& Furudate 1996, Tohei et al. 1997, Yamahnouchi et al. 1997). In these conditions a decrease in pituitary prolactin synthesis was observed (Vale et al. 1973, Seo et al. 1979, Jahnke et al. 1980), as well as an increase in SP and TSH synthesis (Arita et al. 1993, Jones et al. 1994) and in the cell population that secretes them (Lloyd et al. 1990). Therefore, the increase in intrapituitary SP induced by primary hypothyroidism might interfere with the effect of TRH on lactotrophs without affecting TSH secretion.

In brief, the present study shows that TRH stimulates ir-SP release and increases ir-SP content in the anterior pituitary. In addition, a paracrine interaction between TRH and intrapituitary SP seems to control prolactin release. SP appears to have concentration-dependent, differential effects on prolactin release. SP may act as a physiological modulator of TRH effect on prolactin release and may also fine-tune the lactotroph response to TRH.

\section{Acknowledgements}

The authors thank Dr L Debeljuk for providing the anti-SP serum. This project was funded by grants from Universidad de Buenos Aires and Consejo Nacional de Investigaciones Científicas y Técnicas, Argentina.

\section{References}

Afione S, Debeljuk L, Seilicovich A, Pisera D, Lasaga M, Díaz MC \& Duvilanski BH 1990a Substance P affects the GABAergic system in the hypothalamo-pituitary axis. Peptides 11 1065-1068.

Afione S, Duvilanski BH, Seilicovich A, Lasaga M, Díaz MC \& Debeljuk L 1990 b Effect of serotonin on the hypothalamic-pituitary GABAergic system. Brain Research Bulletin 25 245-249.

Apfelbaum ME 1998 Role of vasoactive intestinal peptide and $5-\mathrm{HT}_{2}$ receptor subtype in serotonin stimulation of basal and thyrotropinreleasing-hormone-induced prolactin release in vitro from rat pituitary cells. Neuroendocrinology 67 45-50.

Appel KC, Babb BE, Goswami R, Hall PL, Lawrence KB, Logan ME, Przyklek-Elling R, Tomczuk BE, Vepanelli BR \& Yanni JM 
1991 Imidazo[4,5-b]quinoxaline cyanines as neurokinin antagonist. Journal of Medical Chemistry 43 1751-1753.

Arita J, Kojima Y \& Kimura F 1993 Measurement of the secretion of a small peptide at a single cell level by the cell immunoblot assay: thyroidectomy increases the number of substance P-secreting anterior pituitary cells. Endocrinology 132 2682-2688.

Arita J, Kojima Y, Yamamoto I, Mazawa S \& Kimura F 1994 Somatotropes and thyrotropes in the anterior pituitary gland cosecrete substance P: analysis by the sandwich cell immunoblot assay. Neuroendocrinology 60 567-574.

Arisawa M, Snyder G \& McCann SM 1989 Effect of substance P on thyrotropin secretion from the pituitary gland in the rat. Peptides $\mathbf{1 0}$ 763-766.

Aronin N, Coslovsky R \& Chase K 1988 Hypothyroidism increases substance $\mathrm{P}$ concentration in heterotopic anterior pituitary. Endocrinology 122 2911-2914.

Balsa JA, Cacicedo L, Lara JI, Lorenzo MJ, Pazos F \& Sánchez-Franco F 1996 Autocrine and or paracrine action of vasoactive intestinal peptide on thyrotropin-releasing hormone-induced prolactin release. Endocrinology 137 144-150.

Bhom SK, Grady EF \& Bunnett NW 1997 Regulatory mechanisms that modulate signalling by G-protein-coupled receptors. Biochemistry Journal 322 1-18.

Brown ER, Roth KA \& Krause JE 1991 Sexually dimorphic distribution of substance $\mathrm{P}$ in specific anterior pituitary cell populations. PNAS 88 1222-1226.

Bruhn TO, Rondeel JMM, Bolduc TG \& Jackson IMD 1994 Thyrotropin-releasing hormone (TRH) gene expression in the anterior pituitary. I. Presence of pro-TRH messenger ribonucleic acid and pro-TRH-derived peptide in a subpopulation of somatotrophs. Endocrinology 134 815-820.

De Palatis L, Khoram O \& McCann SM 1985 Age, sex, and gonadal steroid-related changes in immunoreactive substance $\mathrm{P}$ in the rat anterior pituitary gland. Endocrinology 117 1368-1373.

Debeljuk L, Lasaga M, Afione S, Duvilanski BH \& Díaz MC 1988 Effect of passive immunization against substance $\mathrm{P}$ in rats with hyperprolactinemia. Peptides 9 933-936.

Duvilanski BH, Lasaga M, Seilicovich A, Afione S, Díaz MC \& Debeljuk L 1990 Vasoactive intestinal peptide affects the GABAergic system in the hypothalamic-pituitary axis. Brain Research Bulletin 25 215-219.

Farrow SM 1993 Post-transcriptional regulation of hormone synthesis. Journal of Endocrinology 138 363-368.

Goettl VM \& Larson AA 1994 Activity at phencyclidine and mu opioid sites mediates the hyperalgesic and antinociceptive properties of $\mathrm{N}$-terminus of SP in a model of visceral pain. Neuroscience $\mathbf{6 0}$ 375-382.

Jahnke G, Nicholson G, Greeley GH, Youngblood WW, Prange AJ \& Kizer J 1980 Studies on the neural mechanisms by which hypothyroidism reduce prolactin secretion in the rat. Brain Research 191 429-441.

Jessop DS, Chowdrey HS, Larsen PJ \& Lightman SL 1992 Substance P: multifunctional peptide in the hypothalamo-pituitary system. Journal of Endocrinology 132 331-337.

Jonassen JA, Mullikin-Kilpatric D, McAdam A \& Leeman SE 1987 Thyroid hormone regulates preprotachykinin-A gene expression in male rat anterior pituitary. Endocrinology 121 1555-1561.

Jones PM, Ghatei MA, Wallis SC \& Bloom SR 1994 Differential response of neuropeptide $\mathrm{Y}$, substance $\mathrm{P}$ and vasoactive intestinal polypeptide in the rat anterior pituitary gland to alterations in thyroid status. Journal of Endocrinology 143 393-397.

Ju G, Liu SJ \& Zhang X 1991 Peptidergic innervation of the pars distalis of the adenohypophysis. Neuroendocrinology $\mathbf{5 3}$ (Suppl 1) 41-44.

Kimura T \& Furudate S 1996 Pituitary GH and prolactin deficiency and testis enlargement in hypothyroid rats caused by goitrogen methimazole. Experimental Animals 45 369-375.
Larsen P, Saermark T \& Mau S 1992 Binding of an iodinated substance $\mathrm{P}$ analogue to cultured anterior pituitary prolactin- and luteinizing hormone-containing cells. Journal of Histochemistry and Cytochemistry 40 487-493.

Liu YY, Morris JF \& Ju G 1996 Synaptic relationship of substance P-like-immunoreactive nerve fibers with gland cells of the anterior pituitary in the rat. Cell and Tissue Research 285 227-234.

Lloyd RV, Jin L, Song J, Terry LC, Horvath E \& Kovacs K 1990 Effect of propylthiouracil on growth hormone and prolactin messenger ribonucleic acids in the rat pituitary. Laboratory Investigation 62 347-354.

Maggi CA 1995 The mammalian tachykinin receptors. General Pharmacology 26 911-944.

Mau SE \& Saermark T 1991 Substance P stimulation of polyphosphoinositide hydrolysis in rat anterior pituitary membranes involves a GTP-dependent mechanism. Journal of Endocrinology 130 63-70.

Mau SE, Larsen PJ, Mikkelsen JA \& Saermark T 1990 Substance P and related tachykinins induce receptor-mediated hydrolysis of polyphosphoinositides in the rat anterior pituitary. Molecular and Cellular Endocrinology 69 69-78.

Mikkelsen JD, Larsen PJ, Moller M, Vilhart H \& Saermark T 1989 Substance $\mathrm{P}$ in the median eminence and pituitary of the rat: demonstration of immunoreactive fibers and specific binding sites. Neuroendocrinology 50 100-108.

Mizukami M, Kishida S, Hirai M, Ooya E, Nakai T \& Miyabo S 1993 The effects of short and long duration of hypothyroidism on prolactin secretion in rats. Nippon Naibunpi Gakkai Zassahi 69 $1129-1138$.

O'Halloran DJ, Jones PM, Ghatei MA, Domin J \& Bloom SR 1990 The regulation of neuropeptide expression in rat anterior pituitary following chronic manipulation of estrogen status: a comparison between substance $\mathrm{P}$, neuropeptide $\mathrm{Y}$, neurotensin, and vasoactive intestinal peptide. Endocrinology 127 1463-1469.

O'Halloran DJ, Jones PM, Ghatei MA \& Bloom SR 1991 Rat anterior pituitary neuropeptides following chronic prolactin manipulation: a combined radioimmunoassay and mRNA study. Journal of Endocrinology 131 411-419.

Ozawa K, Szallasi Z, Kazanietz MG, Blumberg PM, Mischak H, Mushinski JF \& Beaven MA $1993 \mathrm{Ca}^{++}$-dependent and $\mathrm{Ca}^{++}$ independent isozymes of protein kinase $\mathrm{C}$ mediate exocytosis in antigen-stimulated rat basophilic RBL-2H3 cells. Reconstitution of secretory responses with $\mathrm{Ca}^{++}$and purified isozymes in washed permeabilized cells. Journal of Biological Chemistry 268 1749-1756.

Peillon F, LeDafniet M, Pagesy P, Croissandeau G, Schussler N, Joubert N \& Li JY 1997 Paracrine regulation of anterior pituitary hormones by neuropeptides. Annals of Endocrinology $\mathbf{5 8}$ 31-38.

Sanders MA \& LeVine HR 1996 Desensitization of the neurokinin 1 receptor is mediated by the receptor carboxy-terminal region, but is not caused by receptor internalization. Journal of Neurochemistry $\mathbf{6 7}$ 2362-2372.

Seilicovich A, Duvilanski BH, Debeljuk L, Lasaga M, Afione S, Pisera D, Traktenberg R \& Díaz MC 1990 Ethanol-related changes in substance $\mathrm{P}$ in the hypothalamus and anterior pituitary. Regulatory Peptides 31 93-100.

Seilicovich A, Duvilanski B, Gimeno M, Franchi AM, Pisera D \& Lasaga M 1993 Formation of arachidonate metabolites through the lipoxygenase pathway during VIP- and Substance P- induced prolactin release. Neuroendocrinology Letters 15 183-190.

Seo H, Refetoff S, Martino E \& Vassart G 1979 The differential stimulatory effect of thyroid hormone on growth synthesis and estrogen on prolactin synthesis due to accumulation of specific messenger ribonucleic acids. Endocrinology 104 1083-1090.

Shamgochian MD \& Leeman SE 1992 Substance P stimulates luteinizing hormone secretion from anterior pituitary cells in culture. Endocrinology 131 871-875. 
Sharif N 1990 A novel substance P binding site in rat brain regions modulates TRH receptor binding. Neurochemistry Research $\mathbf{1 5}$ 1045-1049.

Simasko SM, Durkin JA \& Weiland GA 1987 Effects of substance P on nicotinic acetylcholine receptor function in PC12 cells. Journal of Neurochemistry 49 253-260.

Sowers JR \& Sollars E 1980 Effect of rendering male rats hypothyroid at different stages of development on adenohypophysial hormone release. Hormone and Metabolic Research 12 524-528.

Tohei A, Akai M, Tomabechi T, Mamada M \& Taya K 1997 Adrenal and gonadal function in hypothyroid adult male rats. Journal of Endocrinology 152 147-154.

Tohei A, Imai A, Watanabe G \& Taya K 1988 Influence of thiouracil-induced hypothyroidism on adrenal and gonadal functions in adult female rats. Journal of Veterinary Medical Science 60 439-446.

Vale W, Blackwell R, Grant G \& Guillemin R 1973 TRF and thyroid hormones on prolactin secretion by rat anterior pituitary cells in vivo. Endocrinology 93 26-33.

Vijayan E \& McCann SM 1979 In vivo and in vitro effects of substance $\mathrm{P}$ and neurotensin on gonadotropin and prolactin release. Endocrinology 105 64-68.

Weintraub BD 1995 Diverse mechanisms for regulation of hormone synthesis and action: relationship to endocrine disease and human genome project. In Molecular Endocrinology: Basic and Clinical Correlations, pp 1-11. Eds BD Weintraub. New York: Raven Press Ltd.

Wormald PJ, Millar RP \& Kerdelhue B 1989 Substance P receptors in human pituitary: a potential inhibitor of luteinizing hormone secretion. Journal of Clinical Endocrinology and Metabolism 69 612-615.

Yamahnouchi H, Kitauchi S \& Shiino M 1997 Changes in prolactin secretion in postnatal rats and effect of neonatal thyroidectomy. Molecular and Cellular Endocrinology 134 101-107.

Yoshikawa K \& Hong J-S 1983 Sex related differences in substance P level in rat anterior pituitary. Brain Research 273 362-365.

Yu R \& Hinkle M 1998 Signal transduction, desensitization, and recovery of responses to thyrotropin-releasing hormone after inhibition of receptor internalization. Molecular Endocrinology 12 737-749.

Received 7 September 1999

Revised manuscript received 28 March 2000

Accepted 18 April 2000 